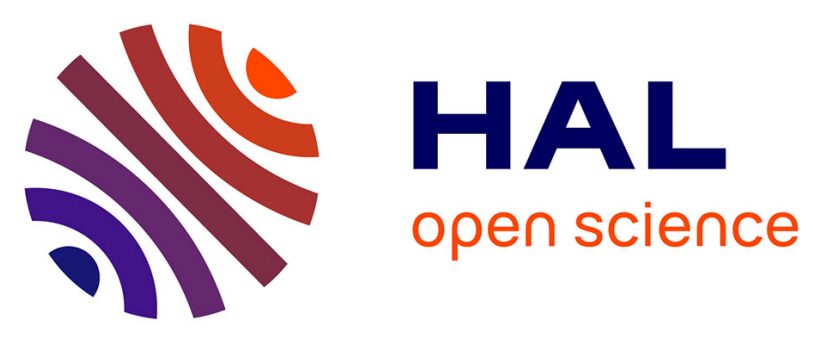

\title{
Osidasic profiles in the digestive tract of some omnivorous and herbivorous continental fishes of the French Guiana
}

\author{
René Lesel, R. Rojas-Beltran, J.M. Blanc, M. Rouel, M. Lesel
}

\section{To cite this version:}

René Lesel, R. Rojas-Beltran, J.M. Blanc, M. Rouel, M. Lesel. Osidasic profiles in the digestive tract of some omnivorous and herbivorous continental fishes of the French Guiana. Aquatic Living Resources, 1988, 1 (1), pp.53-57. hal-02722053

\section{HAL Id: hal-02722053 \\ https://hal.inrae.fr/hal-02722053}

Submitted on 1 Jun 2020

HAL is a multi-disciplinary open access archive for the deposit and dissemination of scientific research documents, whether they are published or not. The documents may come from teaching and research institutions in France or abroad, or from public or private research centers.
L'archive ouverte pluridisciplinaire $\mathbf{H A L}$, est destinée au dépôt et à la diffusion de documents scientifiques de niveau recherche, publiés ou non, émanant des établissements d'enseignement et de recherche français ou étrangers, des laboratoires publics ou privés. 


\title{
Osidasic profiles in the digestive tract of some omnivorous and herbivorous continental fishes of French Guiana
}

\author{
René Lésel ${ }^{(1)}$, Ricardo Rojas-Beltran ${ }^{(2)}$, Jean-Marie Blanc ${ }^{(3)}$, Michèle Rouel ${ }^{(1)}$ \\ and Michèle Lésel ${ }^{(1)}$ \\ (1) INRA, Station d'Hydrobiologie, Laboratoire des Microorganismes \\ B.P. 3, Saint-Pée-sur-.Vicelle, 64310 Ascain (France) \\ (2) INRA, Institut de Limnologie, 75, acenue de Corzent. \\ B.P. II, 74203 Thonon-les-Bains cedex (France) \\ (3) I,YRA, Station d'Hydrobiologie, Laboratoire de Nutrition des Poissons, \\ B.P.3, Saint-Pée-sur-sitelle, 64310 Ascain (France). \\ Accepted Octoher 12, 1987.
}

\begin{abstract}
A study of the osidasic profile in the digestive tract of some herbivorous fish species living in tropical freshwaters of French Guiana has been undertaken. Osidase APY-ZYM plates allowing the . study of the last stages of the polyosides lysis were used. The results show that Arius parkeri and Arius couma have low scores but without any staring enzymatic particularities; Myleus ternetzi gives similar results. Compared with the species. Leporinus granti and Hoplosternum thoracatum have more diversified and increasing scores; Hypostomus watwata exhibits a number of striking top performances and general superiority over other species.

These preliminary results are discussed according to the possible fish aptitude to digest complex glucids of the diet.
\end{abstract}

Léscl R., R. Rojas-Beltran, B. J. M. Blanc, M. Rouel, M. Lésel, Aquat. Liting Resour., 1988, 1, 5357.

Keywords : Osidase, herbivorous fishes, freshwater, French Guiana.

Profils osidasiques dans le tractus digestif de quelques poissons d'eau douce omnicores et herbitores de Gujane Française.

Résumé

Une étude du profil osidasique dans le tractus digestif de quelques espèces de poissons herbivores des eaux douces de la Guyane Française a ćté réalisée. Les plaques API-ZYM Osidases permettant l'étude des derniers stades de lyse des polyosides ont été utilisées. Chez Arius parkeri et Arius couma, les résultats sont faibles et il n'apparait pas d'activité remarquable; Myleus ternetzi donne des résultats analogues. Comparécs à ces trois especces, Leporinus granti et Iloplosternum thoracatum donnent des résultats plus variés et plus élevés; chez Hypostomus watwata on observe un grand nombre de résultats élevés et dans l'ensemble supérieurs à ceux des autres espèces.

Ces résultats préliminaires sont analysés en fonction d'une éventuelle aptitude des espèces à digérer les glucides complexes de leur alimentation.

Mots-clés : Osidase, poissons herbivores, eau douce, Guyane Française. 


\section{INTRODUCTION}

The bacterial flora of the digestive tract in fish living in temperate and cold waters, due to the low temperature and absence of compartment allowing a high multiplication, cannot give rise to its metabolic abilities. This may be possible in herbivorous species living in tropical waters.

Recent researches indicate that cellulolytic activity is low in fish (Prejs and Blaszczyk, 1977; Niederholzer and Hofer, 1979). Even in fish considered to be herbivorous, e.g. the grass carp Ctenopharyngodon idella (Lésel M. et al., 1985; Lésel et al., 1986a) it has not been possible to detect either a high cellulasic activity or a sizeable bacterial population able to digest cellulose in the intestine. It was impossible to observe any difference between two cyprinids, the grass carp, C. idella, considered to be herbivorous and the goldfish, Carassius auratus, which is omnivorous. The study of the osidasic profile in the digestive tract of these species at $20^{\circ} \mathrm{C}$ and at $28^{\circ} \mathrm{C}$ (Lésel et al., 1986 b) showed no significant temperature effect on overall enzyme production. However, such an effect did exist for some of these enzymes.

A study of the osidasic profile in the digestive tract of tropical fish species has been undertaken. Specimens collected in French Guiana belonging to six species:

- 4 Siluriform fishes: two Ariidae, Arius couma (Val., 1839) and $A$. parkeri (Trail, 1832); one Callichthyidae, Hoplosternum thoracatum; (Cuvier et Val., 1840); one Loricariidae, Hypostomus watwata (Hancock, 1828);

- 2 Characoid fishes: one Serrasalmidae, Myleus ternetzi (Norman, 1929) and onc Anostomidae, Leporinus granti (Eigenmann, 1912).

were investigated.

The aim of this work was to define the osidasic abilities in the last stages of the lysis of complex glucids: chitin, pectin, starch, hemicellulose and cellulose.

\section{MATERIAL AND METHODS}

\section{Biological material}

Six different fish species were collected by trammel netting in Sinnamary and Kourou rivers (French Guiana).

- Arius parkeri (common name: "mâchoiran jaune") and Arius couma (common name: "couman couman"). We collected $1 A$. parkeri and $6 A$. couma. These species live in estuarine waters, $A$. couma being able to live in freshwaters up to the first rapids of the rivers. Their digestive tract is medium-sized (intestinal coefficient: $A$. couma 2.39; $A$. parkeri 1.71 , RojasBeltran, 1984). They are benthic species with an omnivorous diet and carnivorous tendency.
- Myleus ternetzi (common name: "pacoucine"). Ten specimens were collected. This species, living strictly in freshwater environment, is herbivorous and grazes the immerged leaves of trees and seeds fallen down in water. The length of the digestive tract is medium-sized. Intestinal coefficient: 2.91.

- Leporinus granti (common name: "carp"). Five specimens of this small herbivorous detritivorous species living solely in freshwater environment were collected. The intestinal coefficient is about 1.50.

- Hoplosternum thoracatum (common name: "attipa rouge"). We collected 5 specimens of this species in freshwater but which may be also found in brackish environment. It has an omnivorous diet with a carnivorous tendency. The digestive tract is relatively short. The intestinal coefficient is about 1.50 to 2.

- Hypostomus watwata (common name: "goret"). We collected 8 specimens. It is a freshwater species living at the fringe of brackish waters during breeding time. It feeds on sea-weeds and benthic diatoms. It has a long digestive tract. Intestinal coeflicient: 7 to 18 (Nomura et al., 1981); a specimen $30 \mathrm{~cm}$ long, collected in Kourou river, had a digestive tract measuring approximately $8 \mathrm{~m}$.

\section{Detection of enzymes}

As described in a previous study (Lésel et al., $1986 b$ ), the osidase API-ZYM system was used for the detection of 20 cnzymes. Enzyme detection was carried out with a centrifuged, filtrated ground gut suspension (6000 r.p.m.). The inoculated $\triangle$ PI-ZYM strips were incubated for $4 \mathrm{~h}$ at $34^{\circ} \mathrm{C}$. Then a drop of $0.1 \mathrm{~N} \mathrm{NaOH}$ was added to each cupule, and the results read $10 \mathrm{~min}$ later. Each cupule received a score varying from 0 to 5 according to the intensity of the ycllow colour obtained.

\section{Statistical methods}

The discrete and often skewed nature of the enzymatic activity scores leads to use non-parametric statistical procedures (Siegel, 1956):

- between-species differences concerning each enzyme were tested using the Kruskal-Wallis one-way analysis of variance, and the Mann-Whitney U-test for two-by-two comparisons;

- between-species differences concerning the average enzymatic activity were tested using the Friedman two-way analysis of variance, and the Wilcoxon matched-pairs signed-ranks test for two-by-two comparisons.

\section{RESULTS}

The mean scores of enzymatic activity are presented in table 1 , along with corresponding statistical conclusions. 
Table 1. - Enzymatic activity mean scores and significant differences between fish species.

\begin{tabular}{|c|c|c|c|c|c|c|c|}
\hline $\begin{array}{l}\text { Species (a) } \\
\text { sample size }\end{array}$ & $\begin{array}{c}\mathrm{Ap} \\
1\end{array}$ & $\begin{array}{c}\text { Ac } \\
6\end{array}$ & $\begin{array}{l}\text { Mt } \\
10\end{array}$ & $\begin{array}{c}\mathrm{Lg} \\
5\end{array}$ & $\begin{array}{c}\mathrm{Ht} \\
5\end{array}$ & $\begin{array}{c}H w \\
8\end{array}$ & $\begin{array}{c}\text { Significant } \\
\text { differences }(b)\end{array}$ \\
\hline $1 \propto \mathrm{D}$-galactosidase & 1 & 0.2 & 2.9 & 0.4 & 0.4 & 4.1 & Ac, Lg, $H \mathrm{t} \ll M \mathrm{Mt}<\mathrm{Hw}$ \\
\hline 2 B D-galactosidase & 2 & 2.0 & 3.2 & 4.0 & 3.0 & 4.9 & $A c<M t \& H w ; A c, H t<L g<H w$ \\
\hline $4 \propto$ L-arabinosidase & 0 & 0.7 & 3.2 & 0.4 & 0.0 & 0.0 & $A c, \mathrm{Lg}, \mathrm{Jt}, \mathrm{Hw} \ll \mathrm{Mt}$ \\
\hline $5 \propto D$-glucosidase & 4 & 4.3 & 2.7 & 4.0 & 4.6 & 4.1 & $\mathrm{Mt}<\mathrm{Ac}, \mathrm{Lg}, \mathrm{Ht}, \mathrm{Hw}$ \\
\hline 6 B D-glucosidase & 0 & 0.7 & 2.0 & 1.2 & 1.0 & 5.0 & Ac, Mt, Lg, Ht $\ll \mathrm{Hw}$ \\
\hline $9 \alpha$-maltosidase & 3 & 3.7 & 2.4 & 3.8 & 4.2 & 4.1 & $M t \& A c, L g, I t h, I / w$ \\
\hline $10 \beta$-maltosidase & 0 & 0.8 & 1.9 & 1.2 & 1.4 & 5.0 & Ac, $\mathrm{Mt}, \mathrm{Lg}, \mathrm{Ht} \ll \mathrm{Hw}$ \\
\hline $11 \mathrm{~N}$-acetyl $\alpha \mathrm{D}$-glucosaminidase & 0 & 0.0 & 0.0 & 0.2 & 0.2 & 0.0 & N.S. \\
\hline $12 \mathrm{~N}$-acetyl $\beta \mathrm{D}$-glucosaminidase & 4 & 5.0 & 4.5 & 4.0 & 4.6 & 5.0 & $\mathrm{Lg} \ll A c, 1 \mathrm{w}$ \\
\hline $13 \alpha$ L-fucosidase & 1 & 1.7 & 2.3 & 0.6 & 3.0 & 3.6 & $\mathbf{L g} \& \mathrm{Ht}, \mathrm{Hw}$ \\
\hline 14 B D-fucosidase & 0 & 0.5 & 0.4 & 1.6 & 0.0 & 5.0 & Ac, Mt, Lg, $H_{t} \ll H w$ \\
\hline $19 \propto \mathrm{D}-\mathrm{xy}$ losidase & 0 & 0.0 & 0.9 & 0.1 & 0.0 & 0.0 & $\mathrm{Ac}, \mathrm{Lg}, \mathrm{Ht}, \mathrm{Hw}<\mathrm{Mt}$ \\
\hline $20 \beta D$-xylosidase & 0 & 0.2 & 0.1 & 0.1 & 0.0 & 2.9 & Ac, Mt, Lg, Ht $\ll I I w$ \\
\hline Average activity & 1.25 & 1.46 & 1.74 & 1.74 & 1.95 & 3.23 & $A \mathrm{p}, \mathrm{Ac}<\mathrm{Ht}<\mathrm{Hw} ; \mathrm{Ml}, \mathrm{Lg} \ll \mathrm{Hw}$ \\
\hline
\end{tabular}

(a) Ap=Arius parkeri; $\mathrm{Ac}=$ Arius couma; $\mathrm{Mt}=$ Myleus ternetzi; $\mathrm{Lg}=$ Leporinus granti; $\mathrm{Ht}=$ Hoplosternum thoracatum; $\mathrm{H}$ w $=$ Hypostomus $_{\mathrm{y}}$ watwata.

(b) Arius parkeri excluded; N.S. $=$ not signifiant; $<=$ significant at $p=0.05 \ll=$ significant at $p=0.01$.

- Arius parkeri, being sampled by a single individual, shows no significant difference with any other species in any enzyme. Its enzymatic scores and average score are close to those of Arius couma. Though lacking any staring enzymatic particularity, these Arius sp. have a general tendency for lower scores ( $\beta \mathrm{D}$-galactosidase, $\beta \mathrm{D}$-glucosidase, $\beta \mathrm{D}$-glucuronidase, $\beta$-maltosidase).

- Myleus ternetzi is characterized by particularly low scores (phospho $\beta \mathrm{D}$-galactosidase, $\alpha \mathrm{D}$-glucosidase, $\alpha$-maltosidase) or as low as Arius sp. ( $\beta D$ galacturonohydrolase, $\beta D$-glucuronidase, $\alpha \mathrm{D}$-mannosidase), and some superior scores ( $\alpha$ L-arabinosidase, $\alpha \mathrm{D}$-xyloxidase) or outclassed by Hypostomus natwata only ( $\alpha \mathrm{D}$-galactosidase).

- Leporinus granti and IIoplosternum thoracatum have medium performances and can hardly be distinguished from other species and from each other. Relatively low scores are found in $\alpha \mathrm{D}$-galactosidase and $\beta D$-galactosidase. On the other hand, relatively high scores (close to Hypostomus natwata) are found in $\beta D$-galacturonohydrolase and $\beta D$-glucuronidase. Two particularities, however, are a superior score of Hoplosternum thoracatum (phospho- $\beta$ D-galactosidase) and an inferior score of Leporinus granti ( $\beta \mathrm{D}$ mannosidase).

- Lastly, Hypostomus watwata exhibits a number of striking top-performances and a general superiority over every other species examined here. Most cleancut cases are those of $\alpha D$ and $\beta D$-galactosidase, $\beta D$-glucosidase, $\beta$-maltosidase, $\beta D$-fucosidase, $\beta D$ lactosidase, $\alpha D$-mannosidase and $\beta D$-xylosidase.

\section{DISCUSSION AND CONCLUSION}

Each enzyme may have two different origins: an endogenous one (the fish), and an exogenous one (food and bacteria). The detected activity is the sum of these 2 possibilities in an undetermined ratio. To analyse the possible enzymatic activity, we have considered that the minimum average score of each enzyme must be at least 3.5. The presence of specific enzymes indicates the possible metabolic end products of complex osids in the digestive tract; therefore these diet components may be digested when they are ingested by fish.

$A$. couma and A. parkeri are characterized by a slight enzymatic activity ( $f$ ig. 1 ); 3 enzymes seem capable to have a function in the digestive tract: $N$ acetyl- $\beta D$-glucosaminidase, $\alpha D$-glucosidase and $\alpha$ maltosidase ( $\alpha$-amylase). Three complex glucides might undergo an enzymatic lysis: chitin, starch and probably pectin. These results are in agreement with the omnivorous diet and carnivorous tendency of these fishes.

Enzymatic concentrations are generally higher in $M$. ternetzi than in $A$. couma and $A$. parkeri, but only $\mathrm{N}$-acetyl $\beta \mathrm{D}$-glucosaminidase is abundant enough to have an effective activity ( $f i g .1)$, This leaves and seeds consuming species is able to digest chitin of animal origin. The slight concentrations of $\alpha$ and $\beta D$. galactosidase, $\alpha \mathrm{D}$-glucosidase, $\alpha \mathrm{L}$-arabinosidase and $\beta D$-glucuronidase suggest that this fish takes advantage of its vegetable harvest in a limited way; it may partly lyse pectin, hemicellulose, mucopolysaccharides 
Arlus couma - Arlus parterl

Chitrin $\rightarrow N$-acetylglucosomine

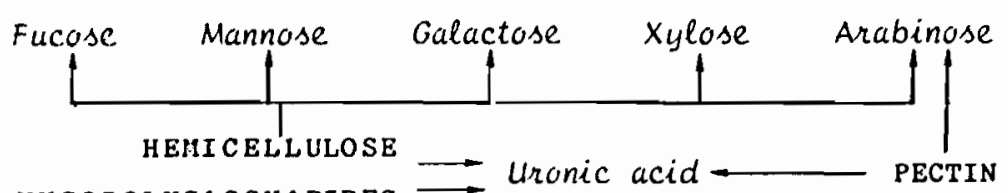

CELLULOSE Cellobiose

MUCOPOLYSACCHARID

Uronic acid

PECTIN

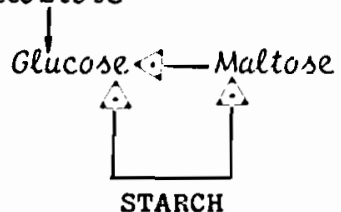

Eysue ternetzl

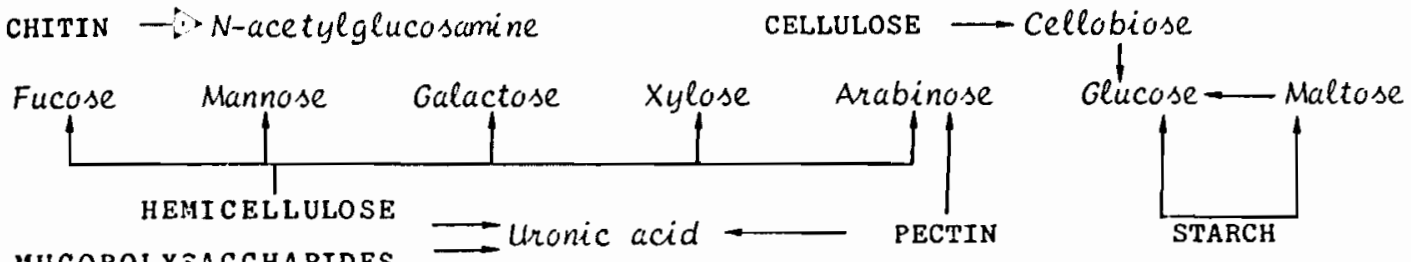

MUCOPOLYSACCHARIDES

Leporisus erentl

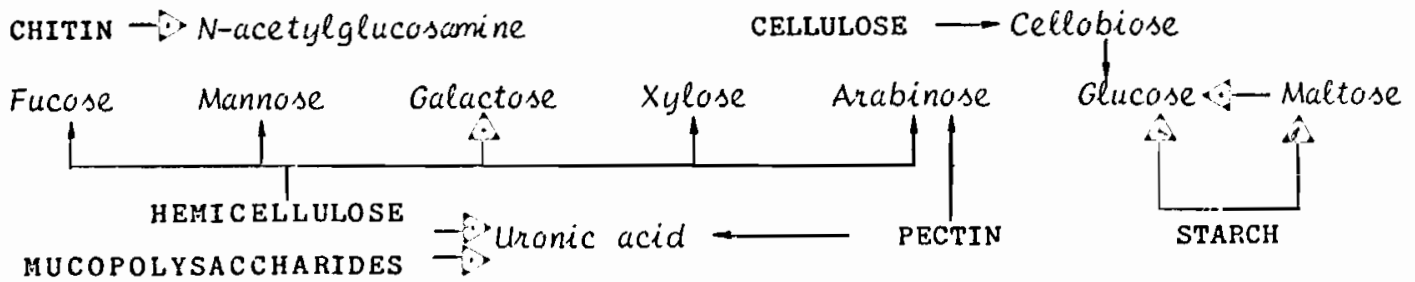

Hoplosternum theracatum

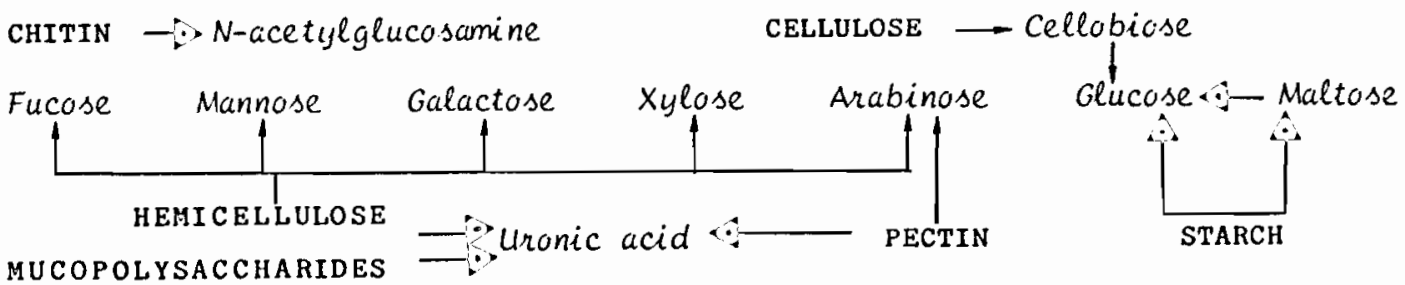

Hypostomus wotwata

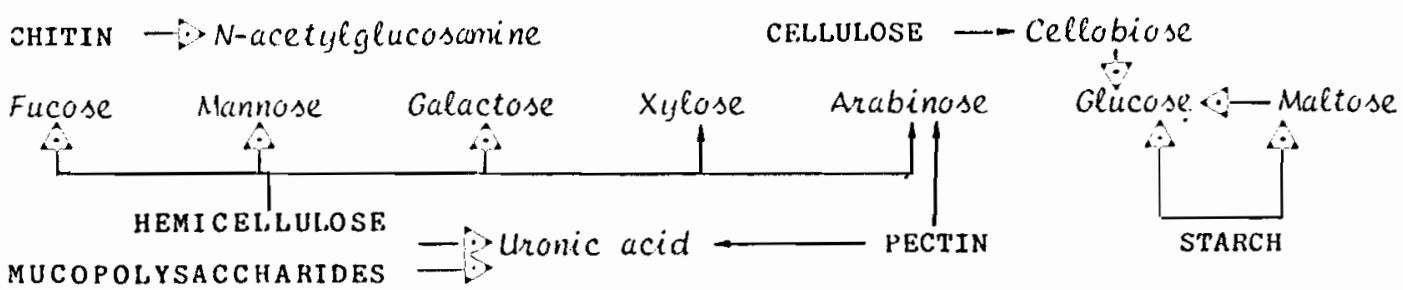

Figure 1. - Specific osidases of the last stages of polyosides lysis in 5 tropical fish species. 
and liberate cellular contents in the digestive compartments.

$L$. granti and $H$. thoracatum are able to digest chitin, starch, pectin, hemicellulose and mucopolysaccharides, the second species having slightly more diversified possibilities. Though not having the same diet, the 2 species have similar enzymatic capacities.

Among the sampled species, II. Watwata has the highest enzymatic diversity and the most important average activity. These characteristics must be related to its anatomic particularity, which is a long digestive tract where bacteria may multiply. At the average environmental temperature of $27^{\circ} \mathrm{C}$, such a characteristic gives to $I I$. watwata an evident capacity (Trust et al., 1979) to digest an important part of animal and vegetal complex glucids: chitin, starch, pectin, hemicellulose, mucopolysaccharides and cellobiose. The API-ZYM osidase system does not allow to detcet cnzymes able to digest microcristalline cellulose.
These results may be compared with what is observed in $C$. idella, the grass carp, and $C$. auratus, the goldfish (Lésel et al., 1986b). The enzymatic profile of goldfish looks like that of Arius; the presence of $\beta \mathrm{D}$-galacturono-hydrolase and $\alpha \mathrm{L}$-fucosidase may indicate that the European species has an ability to digest pectin and hemicellulose. In grass carp, the end products of the enzymatic activity may be galactose and arabinose, indicating a possible lysis of hemicellulose. In both cases, these specific osidase activities can be correlated with the diet. Between-species differences obscrved in Guiana fishes could be dict dependent but also associated with the length of digestive tract.

The aim of further studies will be to determine what is the part due to fish enzyme and what is the spccific production of bacterial flora associated with food or living in the digestive tract.

\section{Acknowledgements}

This work was financially supported by a specific convention "Hydrobiologie Tropicale INRA". The authors are grateful to M. Loir for his help in collecting and sampling fishes and to P. Planquette for information concerning Hoplosternum thoracatum.

\section{REFERENCES}

Lésel M., A. Lanusse, R. Lésel, 1985. Capacités cellulolytiques de la flore digestive de deux cyprinidés, la carpe Amour (Ctenopharyngodon idella) et le carassin doré (Carassius auratus) à $14^{\circ} \mathrm{C}$. Verh. Internat. Verein. Limnol., 22, 2591-2597.

Léscl R., C. Fromageot, M. Lésel, $1986 a$. Cellulose digestibility in grass carp, Ctenopharyngodon idella and in goldfish, Carassius auratus. Aquaculture, 54, 11-17.

Lésel R., C. Fromageot, J. M. Blanc, M. Lésel, $1986 b$. Enzymatic profilcs (osidases) of two cyprinids: Ctenopharyngodon idella and Carassius auratus. Aquaculture, 54, 19-25.

Niederholzer R., R. Hofer, 1979. The adaptation of digestive enzymes to temperature, season and diet in roach Rutilus rutilus L. and rudd Scardinius erythrophthalmus L. cellulase. J. Fish Biol., 15, 411-416.

Nomura II., L. Nemoto, L. M. M. Mucller, 1981. Alimentaçao de seis especies de peixes do genero Plecostomus
Walbaum 1782 (Pisces, Loricariidae), do rio Mogi Guaçu sp. In: $\mathrm{II}^{\circ}$ Seminario Regional de Ecologia, Univ. Fed. Sao Carlos, 389-405, Sao Carlos (Bresil).

Prejs A., M. Blaszczyk, 1977. Relationship between food and cellulase activity in freshwater fishes. J. Fish Biol., I1, 447-452.

Rojas-Beltran R., 1984. Régimes alimentaires et croissance de quelques Siluriformes (Arius sp.) de Guyane, In: Résultats de la Convention d'étude portant sur les ressources halieutiques littorales de la Guyane, ISTPM Cayenne, 14-20.

Siegel S., 1956. Non-parametric Statistics for the Behavioural Sciences. McGraw-Hill Book Co., New York, 312 p.

Trust T. J., L. M. Bull, B. R. Currie, J. T. Buckley, 1979. Obligate anaerobic bacteria in the gastrointestina! microflora of the grass carp (Ctenopharyngodon idella), goldfish (Carassius auratus) and rainbow trout (Salmo gairdneri). J. Fish Res. Bd Canada, 36, 1174-1179. 